\title{
Erratum to: Multifunctional mitoxantrone-conjugated magnetic nanosystem for targeted therapy of folate receptor-overexpressing malignant cells
}

Jaleh Barar ${ }^{1,2}$, Vala Kafil ${ }^{1,2}$, Mostafa Heidari Majd ${ }^{1}$, Abolfazl Barzegari ${ }^{1}$, Sajjad Khani ${ }^{1}$, Mohammad Johari-Ahar ${ }^{1,2}$, Davoud Asgari ${ }^{1,2}$, George Coukos ${ }^{3,4}$ and Yadollah Omidi ${ }^{1,2^{*}}$

\section{Erratum to: Journal of Nanobiotechnology (2015)}

\section{3:26}

DOI 10.1186/s12951-015-0083-7

In the original publication of this work [1], the surname of author George Coukos was misspelt as George Cokous.

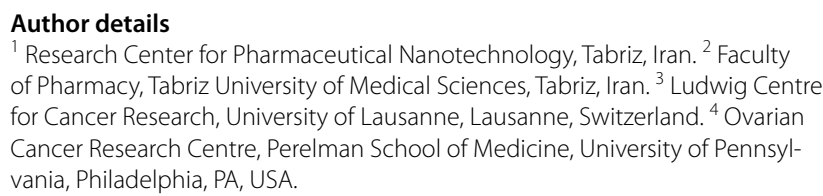

The online version of the original article can be found under doi:10.1186/s12951-015-0083-7.

Received: 3 July 2015 Accepted: 3 July 2015

Published online: 25 September 2015

\section{Reference}

1. Barar J, Kafil V, Majd MH, Barzegari A, Khani S, Johari-Ahar M et al (2015)

Multifunctional mitoxantrone-conjugated magnetic nanosystem for targeted therapy of folate receptor-overexpressing malignant cells. J Nanobiotechnol 13(1):26.

*Correspondence: yomidi@tbzmed.ac.ir

2 Faculty of Pharmacy, Tabriz University of Medical Sciences, Tabriz, Iran

Full list of author information is available at the end of the article 